\title{
Interacciones entre imágenes, textos y sonidos en traducción
}

Rocío García Jiménez

Francisca García Luque

Nieves JimÉnez CarRa
El dosier que a continuación presentamos recoge ocho trabajos de investigación que comparten una característica: abordan el análisis de la traducción de textos en los que conviven elementos lingüísticos, elementos icónicos y a veces elementos acústicos. Se trata, por tanto, de áreas más o menos afines en las que la naturaleza de los textos objeto de análisis exige a los investigadores sobrepasar los límites de la palabra y considerar su combinación con otro tipo de signos para dar cuenta del proceso traductor que subyace en todos ellos.

El artículo que abre el dosier, a cargo de Irene RodríguezArcos, estudia la traducción, relacionándola con la noción de transcreación, como medio para introducir ideologías alternativas, y lo concreta a través del análisis de las campañas publicitarias de la casa Rolex y su relación con la identidad femenina. En los últimos tiempos, Rolex se ha esforzado por ofrecer al mundo una imagen de la mujer que no esté marcada negativamente por estereotipos. En la transmisión de estas nuevas ideas, la traducción desempeña un rol fundamental. En el artículo de Robert Neal Baxter, se analizan las traducciones al asturiano, euskera, catalán y gallego del Manifiesto Comunista, sus paratextos, incluidas las imágenes de las cubiertas, así como el papel que jugaron en la difusión del escrito. Las diferencias entre estas versiones las convierten, según establece el autor, en autónomas tanto unas de otras como del texto origen, pues cumplen funciones diversas. Por su parte, Ángelo Néstore Ferrante estudia la publicación de cómics en la franja temporal entre 2009 y 2015, los años en los que la reciente crisis económica fue más aguda en España. El objetivo es establecer el peso que tuvo el volumen de producción de esta tipología 
16 de textos frente a otras, así como la presencia de ciertas lenguas originales y su tendencia sobre los procesos editoriales.

En el artículo de María del Mar Ogea Pozo, se aborda la traducción de la serie The Big Bang Theory, analizando cómo se han trasladado al español expresiones y términos especializados que, además, contienen una carga humorística. Este análisis de «chistes científicos» permite a la autora clasificarlos desde el punto de vista de la traducción audiovisual del humor, así como establecer qué técnicas más propias de la traducción científico-técnica se han empleado. Una línea similar siguen Vanessa Pérez Rodríguez, Cristina A. Huertas Abril y M. ${ }^{a}$ Elena Gómez Parra, quienes examinan el lenguaje soez $u$ ofensivo empleado en diez episodios de la versión doblada al español peninsular de la serie Breaking $\mathrm{Bad}$. Para ello, las autoras establecen un sistema de fichas en el que se tienen en cuenta los elementos más importantes de los casos de uso de lenguaje soez u ofensivo, así como información relativa a la traducción audiovisual. El objetivo final es dilucidar qué estrategias de traducción se emplean con más frecuencia en el ámbito de la traducción del lenguaje soez en Traducción Audiovisual y si, en este caso concreto, el texto meta ha conservado la efectividad y el registro del texto origen.

Los tres artículos que cierran el dosier comparten el mismo tema: la audiodescripción (AD). El primero de ellos, firmado por Marta Brescia Zapata y Anna Matamala, lo aborda analizando un aspecto concreto, la violencia, y el modo en que es transmitida a través de cuatro estrategias (retención, generalización, especificación y omisión) en un corpus compuesto por tres películas de Quentin Tarantino. El segundo, a cargo de Victoria García Prieto, realiza un análisis tanto en términos cuantitativos como en términos cualitativos sobre la evolución de la oferta de audiodescripción en TVE en los últimos años. El tercer trabajo, cuya autora es Raquel Sanz Moreno, analiza la formación en AD en España, fundamentalmente en los programas de posgrado universitarios, además de en el Grado Superior de especialización en AD y subtitulado para sordos (SpS), aprobado en 2019, para dibujar cómo se encuentra el panorama de la didáctica de la $\mathrm{AD}$ en España en estos momentos y cuáles son los retos a los que se enfrenta.

Los ocho artículos, considerados en su conjunto, reflejan los caminos por los que transita la investigación más actual y duradera dentro de diversas especialidades en las que conviven texto, imágenes y a veces también sonidos. En ellas, prácticas tradicionales, como el doblaje, siguen encontrando su dosis de protagonismo, al mismo tiempo que destaca la investigación llevada a cabo sobre otras modalidades emergentes como la audiodescripción, ubicada dentro del campo de la accesibilidad a los medios. Junto a todo ello, una constante en la investigación traductológica cuando nos adentramos en terrenos donde comparten espacio palabras, imágenes y sonidos: la necesidad de reflexionar sobre los límites del concepto mismo de traducción y redefinirlo para adaptarlo a las nuevas formas de comunicación (y, por ende, de traducción) de nuestras sociedades, en las que la combinación entre textos, imágenes y sonidos desempeña un papel cada vez más notorio. 